\title{
Bushmeat hunting and use in the Makira Forest, north-eastern Madagascar: a conservation and livelihoods issue
}

\author{
Christopher D. GOLDEN
}

\begin{abstract}
In the 2003 Durban Vision the Malagasy government committed to tripling the amount of protected areas in Madagascar by 2009. This extensive expansion needs to involve an assessment of the potential impacts on the people who rely on forest resources for subsistence. Wildlife for human consumption (bushmeat) is one such resource that has received great attention on mainland Africa but has largely been ignored in Madagascar until recently. In terms of biomass, hunting in Madagascar appears to be on a lesser scale compared to areas of mainland Africa. However, because of the life-history characteristics associated with hunted primate and carnivore species in Madagascar even small-scale hunting is a major threat to long-term conservation. In this study I used semistructured interviews to quantify annual rates of bushmeat harvest in 14 villages adjacent to the Makira Forest in north-eastern Madagascar. Interviews revealed that 23 mammal species were hunted for consumption, providing a new insight into the scale and frequency of bushmeat use. Harvest data and life-history information were sufficient to allow quantitative assessments of sustainability for four species of lemur (black and white ruffed lemur Varecia variegata, indri Indri indri, eastern bamboo lemur Hapalemur griseus and white-fronted brown lemur Eulemur albifrons) and a species of the carnivore family Eupleridae (fossa Cryptoprocta ferox). Model results suggest hunting of these species is probably unsustainable. This research presents clear evidence that hunting is a major conservation and livelihoods issue in Madagascar and needs to be considered in the planning stages of protected area development to address better the needs of local people.
\end{abstract}

Keywords Cryptoprocta ferox, Eulemur albifrons, Hapalemur griseus, Indri indri, lemurs, Madagascar, sustainability assessment, Varecia variegata.

\section{Introduction}

Conservationists have long focused on the effects of fragmentation and deforestation as critical factors in

Christopher D. Golden Harvard College, Cambridge, MA, USA. E-mail cgolden@nature.berkeley.edu

Current address: Department of Environmental Science, Policy \& Management, 137 Mulford Hall, Kremen Lab, University of California, Berkeley, CA 94720-3114, USA.

Received 28 October 2007. Revision requested 3 December 2007. Accepted 4 March 2008. species' loss, yet recent research suggests that commercial and subsistence hunting are major threats to wildlife persistence in sub-Saharan Africa ( $\mathrm{Fa}$ et al., 2002; Milner-Gulland \& Bennett, 2003; Brashares et al., 2004). The issue of bushmeat hunting in Madagascar has been understudied, despite Madagascar's status as one of the world's unique biodiversity hotspots (Goodman \& Benstead, 2005). In 2003, at the Fifth World's Park Conference in South Africa, Madagascar's then President Marc Ravalomanana pledged in his Durban Vision to more than triple the system of protected areas from 1.7 million to 6 million ha, c. $10 \%$ of the nation's surface area, by 2009 (Duffy, 2006). This bold commitment was made primarily with ecological and environmental considerations and justifications. To understand better the consequences of this national commitment to local processes of forest access and use it is necessary to study local people's interaction with their forest resources.

Little research has been conducted relevant to the threat of hunting as a risk factor in the conservation of Malagasy mammals. There have been reports of hunting Microchiropteran bats during a famine season (Goodman, 2006), observance of a hunter's butchering site in Ankarafantsika (Garcia \& Goodman, 2003), qualitative observations of hunting in the west (Goodman \& Raselimanana, 2003) and southeast (Bollen \& Donati, 2006), and a study on the social structure and motivations of hunting in the Manangotry region (Randriamanalina et al., 2000). The study reported here therefore quantified the rates of annual harvest to assess the sustainability of current hunting practices in the Makira Forest, north-eastern Madagascar.

The Makira Forest (Fig. 1) is one of the most pristine rainforest blocks remaining in Madagascar, and has recently been declared a protected area as part of the Durban Vision. Within the newly established Makira Protected Area c. 140,000 people reside and rely on forest resources for food. My aim was to quantify rates of harvest and consumption of wildlife and to then compare these rates to estimated values of species production to assess the sustainability of hunting. Understanding the Malagasy system of hunting and the underlying forces driving this system is necessary for development of the most appropriate strategy for addressing bushmeat hunting in this forest.

\section{Study area}

The Makira Forest in north-eastern Madagascar covers 371,217 ha of lowland and mid altitude rainforest. It is one of 


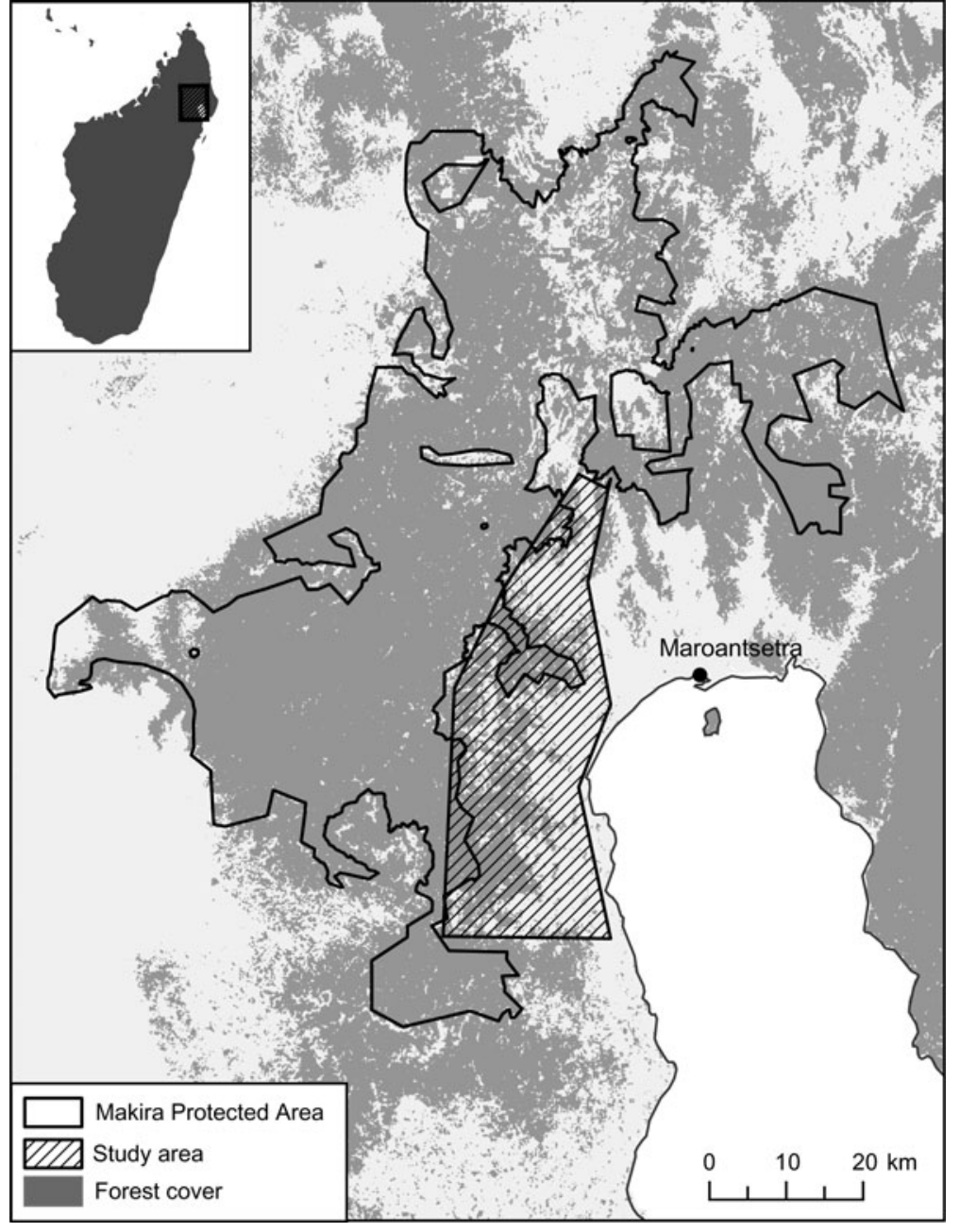

FIG. 1 Location of the study area within the Makira Protected Area. The rectangle on the inset indicates the location of the main figure in north-eastern Madagascar. the most biologically diverse ecosystems in Madagascar and represents one of the nation's largest remaining blocks of contiguous forest. Two tribal affiliations dominate the area, with Betsimisaraka predominant in the east and south, Tsimihety predominant in the north and west, and a mixing where these regions overlap. I studied 14 villages that had access to the Makira Forest (Fig. 1), incorporating both tribal areas.

\section{Methods}

During June-August 2004 I engaged in ethnographic methods of participant observation with members of village hunting cohorts. I followed local hunters into the forest on six occasions, having been invited to observe their hunting missions. These forays were of $1-7$ hour duration, and I observed a variety of hunting methods geared specifically to catch lemur, carnivore, bat and tenrec species.

I conducted semi-structured household interviews in Malagasy with the assistance of a Betsimisaraka research assistant. I interviewed male heads of households in each village and randomly selected households with the help of village informants. I collected quantitative data on annual rates of species' consumption, considering household consumption to equal offtake. This is a reasonable assumption because Malagasy mammals are relatively small and the majority are eaten wholly within one household rather than shared among several. Information gathering was divided into two categories: household interviews and communityknowledge interviews. I surveyed 14 villages and conducted a minimum of 10 household surveys and at least three community knowledge interviews in each community.

In each community knowledge interview I organized three male heads of households into a focus group and asked questions on local species' abundances, people's preferences and annual rates of consumption. This allowed small groups to work together discussing issues of hunting, bushmeat preferences, and perceived trends in populations for particular species. To assess the sustainability of mammal hunting I compared reported harvest rates within specified harvest areas with estimates of available productivity per $\mathrm{km}^{2}$, calculated using the Robinson \& Redford (1991) index.

Robinson \& Redford (1991) assumed that maximum production (Eq. 1) is achieved when the population density 
(D) is at $60 \%$ of carrying capacity, where $P_{\max }$ is the maximum production for a given species and $\lambda_{\max }$ the maximum rate of natural increase, defined in Eq. 2 as the exponential of the intrinsic rate of natural increase $\left(r_{\max }\right)$ :

$$
\begin{aligned}
& P_{\max }=\left(0.6 \mathrm{D} \lambda_{\max }\right)-0.6 \mathrm{D} \\
& \lambda_{\max }=\mathrm{e}^{r_{\text {max }}}
\end{aligned}
$$

$r_{\max }$ was estimated, using Mathematica v. 5.1 (Wolfram Research, Champaign, USA), using a model that incorporated annual birth rate of female offspring (proxied by sex ratio multiplied by average litter size), the age of first reproduction, and the age of last reproduction (Cole, 1954). In cases where sex ratio or age of last reproduction was not found in the literature, a sex ratio of 1:1 was assumed and life expectancy was used as a proxy for age of last reproduction. $\lambda_{\max }$ was calculated (Eq. 2) to estimate the maximum production in Eq. 1 (Table 1).

Density estimates for lemurs were geographically specific to the Makira Forest (Rasolofoson et al., 2007). I used the only available published density estimate for Cryptoprocta ferox (Hawkins \& Racey, 2005), the top predator in Madagascar, which was from a dry, deciduous forest (Table 1). Maximum production was then multiplied by 0.2 because all focal mammals were deemed long-lived (life expectancy $>10$ years), producing an estimate of the portion of maximum production available for sustainable harvest.

Harvest was determined through household interviews by calculating total individuals harvested per year within a delimited area, calculated to be a perfect circle surround- ing a village centre. The radius of the circle was estimated by hunter reports of either distance or time travelled to hunt or trap lemurs. Because I did not collect this information in 2004 I have used data from my research in 2005-2007 to estimate harvest area. Hunting distance for carnivores was not included because that would cause an underestimation of harvest area, as the mean distance would be skewed by the preponderance of farmers who set traps immediately outside their houses as a form of pest control. When only a time travelled to hunt was given it was converted to distance by assuming that $5 \mathrm{~km}$ could be travelled in 1 hour, as the majority of hunts are by foot, along difficult trails that radiate out from the village. Total harvest was determined by extrapolating sampled household harvests to entire village populations, estimating the area of harvest, and then determining the harvest per $\mathrm{km}^{2}$ per year. After summing the extrapolated village harvest values and dividing them by the number of villages, these values were divided by the total harvest area. Total extrapolated harvest was divided by total harvest area to produce an annual harvest for each species.

\section{Results}

I surveyed a total of 312 households in the 14 villages. On average this represented $13.7 \%$ of the households within each village. These villages varied in size (25-450 households). As indicated in these interviews, the prey species that were important in the diet included an array of lemur, carnivore, bat, tenrec and wild bird species. People reported hunting

TABLE 1 Data applied to Robinson \& Redford's (1991) maximum production equation (Eq. 1, see text), and the corresponding available

\begin{tabular}{|c|c|c|c|c|c|c|c|c|}
\hline Species & $\begin{array}{l}\text { Density } \\
\left(\text { no. } \mathrm{km}^{-2}\right)^{1}\end{array}$ & $r_{\max }^{2}$ & $\lambda_{\max }^{3}$ & $\begin{array}{l}\text { Production } \\
\left(\text { no. } \mathrm{km}^{-2} \mathrm{yr}^{-1}\right)^{4}\end{array}$ & $\begin{array}{l}\text { Available } \\
\text { production } \\
\left(\text { no. } \mathrm{km}^{-2} \mathrm{yr}^{-1}\right)^{5}\end{array}$ & $\begin{array}{l}\text { Maximum } \\
\text { harvest } \\
\left(\text { no. } \mathrm{km}^{-2} \mathrm{yr}\right)^{6}\end{array}$ & $\begin{array}{l}\text { Minimum } \\
\text { harvest } \\
\left(\text { no. } \mathrm{km}^{-2} \mathrm{yr}^{-1}\right)^{7}\end{array}$ & $\begin{array}{l}\text { Life span } \\
\text { reference }\end{array}$ \\
\hline Eulemur albifrons & 82.2 & 0.04 & 1.04 & 1.97 & 0.39 & 1.68 & 0.61 & $\begin{array}{l}\text { P.C. Wright } \\
\text { (pers. comm.) }\end{array}$ \\
\hline Hapalemur griseus & 6.8 & 0.13 & 1.14 & 0.57 & 0.11 & 1.03 & 0.38 & $\begin{array}{l}\text { Harvey et al. } \\
\text { (1987) }\end{array}$ \\
\hline Varecia variegata & 11.1 & 0.1 & 1.11 & 0.73 & 0.15 & 1.03 & 0.38 & $\begin{array}{l}\text { Hakeem et al. } \\
\text { (1996) }\end{array}$ \\
\hline Indri indri & 17.5 & 0.15 & 1.16 & 1.68 & 0.34 & 0.65 & 0.23 & $\begin{array}{l}\text { P.C. Wright } \\
\text { (pers. comm.) }\end{array}$ \\
\hline Cryptoprocta ferox & 0.26 & 0.2 & 1.22 & 0.03 & 0.01 & 0.26 & 0.09 & $\begin{array}{l}\text { L.J. Dollar } \\
\text { (pers. comm.) }\end{array}$ \\
\hline
\end{tabular}
production determined by a long life span.

${ }^{1}$ For lemurs, from 12 sampled sites in the Makira Forest (Rasolofoson et al., 2007); for C. ferox, from Hawkins \& Racey (2005)

${ }^{2}$ Calculated with Cole's (1954) method

${ }^{3}$ Calculated by taking the exponential of the $r_{\max }$ values (Eq. 2, see text)

${ }^{4}$ Robinson \& Redford's (1991) method (Eq. 1, see text)

${ }^{5}$ Calculated with Robinson \& Redford's (1991) method

${ }^{6}$ Calculated by extrapolating reported annual consumption values from sampled households to villages, and then dividing these values by the mean harvest area

${ }^{7}$ Calculated by extrapolating reported annual consumption values from sampled households to villages, and then dividing these values by the mean harvest area plus one standard deviation 
and consumption of at least 23 mammal species (Table 2). Ninety-five percent (297 of 312) of households had consumed some type of mammalian bushmeat within the past year and $>50 \%$ of all households participated in eating Eulemur albifrons, a lemur species legally protected against hunting (Table 3). Even though all lemur species are thus protected, participation in hunting of protected species is widespread, as demonstrated by the high prevalence of households consuming these species (Table 3). In the case of C. ferox it is illegal to hunt the species in protected areas but there is a caveat in the law that allows people to interpret that hunting of this species is permissible, stating that is permissible to kill any animal that threatens their livestock or livelihood.

People actively hunted with slingshots (for small carnivore and lemur species), spears (for lemurs and bush pig), nets (for bats) and dogs (for lemur, carnivore and tenrec species). However, hunters harvested the majority of mammals with passive traps and snares, placing snares on animal paths (fandrikandia) for capturing carnivore species and bush pigs. Large wooden structures with trap doors were also used to capture bush pigs. For lemur-hunting two snare types were frequently used that utilize a method of clearing areas of forest to force lemur movement across specified wooden bridges. When these bridges are constructed to connect forest fragments the snares are called laly lava, and can capture lemurs regardless of their preference for particular fruit trees. If the bridges are constructed to connect a fruit tree to surrounding forest fragments, the snares are called laly totoko, and focus on the capture of species that utilize a particular type of fruit tree. In general hunting with guns does not seem to be a major threat to animal populations from local people but wealthier individuals from regional cities will often travel into the Makira Forest to harvest lemurs with their guns.

I collected 86 reports of hunters' travelling distance and 154 reports of hunters' travelling time. Using an approximation of $5 \mathrm{~km}$ travelled per hour, the estimation of mean harvest area proxied by time travelled $(4.57 \pm$ SD $3.07 \mathrm{~km})$ did not differ significantly from hunter's reports of actual distance travelled to hunt ( $4.10 \pm$ SD $2.57 \mathrm{~km})$. By pooling these results, estimated harvest area was $4.40 \pm$ SD $2.90 \mathrm{~km}$.

For the purposes of this analysis I collected data exclusively concerning mammals during the interviews, and only species with enough life history data were included in the assessment of sustainable harvest. These species include four lemur species and one carnivore species of the family Eupleridae: indri Indri indri, black and white ruffed lemur Varecia variegata, white-fronted brown lemur E. albifrons,

TABLE 2 A list of species hunted in the Makira Forest, north-eastern Madagascar (Fig. 1).

\begin{tabular}{|c|c|c|}
\hline Scientific name & Malagasy name* & English common name \\
\hline \multicolumn{3}{|l|}{ Lemurs } \\
\hline Avahi laniger & Ampongy, Fotsife & Eastern woolly lemur \\
\hline Cheirogaleus major & Tsitsiha & Fat-tailed dwarf lemur \\
\hline Daubentonia madagascariensis & Aye-aye & Aye-aye \\
\hline E. albifrons & Varikosa & White-fronted brown lemur \\
\hline Eulemur rubriventer & Tongo & Red bellied lemur \\
\hline H. griseus & Bokombolo & Grey bamboo lemur \\
\hline I. indri & Babakoto & Indri \\
\hline Lepilemur sp. & Fitsidika, Varikandavaka & Sportive lemur sp. \\
\hline Microcebus sp. & Tsidy, Kandrandra & Mouse lemur sp. \\
\hline Propithecus candidus & Simpona & Silky sifaka \\
\hline Varecia rubra & Variniaina & Red ruffed lemur \\
\hline V. variegata & Varikandana & Black and white ruffed lemur \\
\hline \multicolumn{3}{|l|}{ Carnivores } \\
\hline C. ferox & Fosa & Fossa \\
\hline Eupleres goudoti & Falanoka & Falanouc \\
\hline Fossa fossana & Tombokantsodiny & Fanaloka \\
\hline Galidia elegans & Vontsira & Ringtailed mongoose \\
\hline Viverricula indica & Jaboady & Lesser Indian civet \\
\hline \multicolumn{3}{|l|}{ Bats } \\
\hline Minioptera spp. & Manavy & Insectivorous bats \\
\hline Pteropus rufus & Fanihy & Flying fox \\
\hline Rousettus madagascariensis & Andrehy & Madagascar roussette \\
\hline \multicolumn{3}{|l|}{ Bush pig and tenrecs } \\
\hline Potamochoerus larvatus & Lambo Dy & Bush pig \\
\hline Setifer setosus & Sokiny & Greater hedgehog tenrec \\
\hline Tenrec ecaudatus & Trandraka & Common tenrec \\
\hline
\end{tabular}

${ }^{*}$ These names were used in this research to identify species in the Betsimisaraka and Tsimihety dialects in the Makira Forest region. 
TABLE 3 Proportions of villages and households participating in illegal bushmeat hunting.

\begin{tabular}{|c|c|c|c|}
\hline Species & $\%$ of villages ${ }^{1}$ & $\%$ of households ${ }^{2}$ & IUCN status ${ }^{3}$ \\
\hline E. albifrons & 100 & 52 & \\
\hline H. griseus & 93 & 46 & \\
\hline V. variegata & 79 & 14 & CR \\
\hline I. indri & 86 & 9 & EN \\
\hline C. ferox & 57 & 7 & EN \\
\hline
\end{tabular}

${ }^{1}$ Proportion of the 14 study site villages participating in bushmeat hunting of each respective species

${ }^{2}$ Proportion of households participating in bushmeat hunting of each respective species within villages that are hunting this species

${ }^{3} \mathrm{CR}$, Critically Endangered; EN, Endangered (IUCN, 2008)

eastern bamboo lemur Hapalemur griseus, and fossa C. ferox. Eighty-six percent (12 of 14) of villages consumed I. indri, $79 \%$ (11 of 14) consumed V. variegata, $100 \%$ consumed $E$. albifrons, $93 \%$ (13 of 14 ) consumed $\mathrm{H}$. griseus, and $57 \%$ (eight of 14) consumed C. ferox. C. ferox and all of the focal lemur species were found to be hunted unsustainably when using the maximum harvest rate, calculated using the mean harvest area (Table 1). All species with the exception of I. indri were found to be hunted unsustainably when using the minimum harvest rate, calculated using the mean harvest area plus one standard deviation (Table 1).

\section{Discussion}

With a human growth rate of $>3 \%$ Madagascar has one of the most rapidly growing populations of countries that possess rainforest (CIA World Factbook, 2008). Moreover, the population of Madagascar has increased seven fold in the past 100 years (Dewar, 1984). As the Makira Forest becomes increasingly settled, areas that once comprised unexploited wildlife become depleted. Pressure to provide food, complicated by a lack of livestock, creates a multifaceted incentive for bushmeat hunting.

Several questions need to be addressed to develop strategies for the placement of protected areas in Madagascar and to understand the importance of forests to local stakeholders: (1) Are species hunted unsustainably? (2) What methods are used to harvest particular species? (3) To what extent do management regimes in protected areas affect local behaviour with regard to illegal hunting? (4) What role does wild meat play in human nutrition? (5) What are the incentives and deterrents of hunting at a local scale? The research presented here was an attempt to address these first two questions, and further research will be required to address the remaining.

In this study the 14 villages were explicitly chosen to be representative of the entire Makira Forest. Because of this design, the variation between villages is large and a statistical analysis of the confidence intervals of total harvest across villages is not significant. However, this design strengthens the validity of the study as the large sample size of both households and villages allows extrapolations to be made about the entire Makira Forest. Although annual consumption data are frequently biased by recall error, these results are likely to be accurate because rare events, such as the consumption of these focal species, are easily remembered and quantified. Moreover, annual recall may be a superior method to collecting consumption data seasonally and then extrapolating it to a year because hunting behaviour, and thus consumption, is seasonally variable. It is likely, however, that these recalls are an underestimate because people may be hesitant to admit to hunting protected species.

Unlike areas of mainland Africa, Madagascar does not have large-bodied species of wild ungulates and rodents. The introduced bush pig Potamochoerus larvatus, already overharvested and absent in many areas, is the only wild ungulate in Madagascar. The next largest mammal is the fossa, attaining a weight of c. $8.4 \mathrm{~kg}$ (Hawkins, 2003), and the largest primate is the indri, averaging c. $6.5 \mathrm{~kg}$ (Powzyk \& Thalmann, 2003). These species are categorized as Vulnerable and Endangered, respectively, on the IUCN Red List (IUCN, 2008), and life history characteristics indicate they are unlikely to sustain high rates of harvest. Barnes (2002) theorized that following ungulate depletion, hunters will next target primates. Hunting in Madagascar parallels this, in that the absence of ungulate and large rodent species puts increased pressure on lemur and carnivore populations, which serve as a vital source of food, especially in areas that lack accessible and affordable alternatives to bushmeat. Madagascar's unique mammal assemblage, comprising an array of primate and carnivore species that are typically long-lived and slow-reproducing, designate this island as a location particularly susceptible to unsustainable hunting.

In any future research issues of source-sink dynamics must be addressed and incorporated into sustainability analyses. Hunting, especially trapping, can significantly reduce animal populations at the periphery of the forest while the total population of the species in a source area is less influenced (Fitzgibbon et al., 1995). However, primates and other large-bodied and/or slow-reproducing species may not have this same central refuge and are far more likely to be hunted unsustainably (Fitzgibbon et al., 1995), confirming the conclusions of this sustainability analysis. Although these data highlight the risk of unsustainable hunting for I. indri, V. variegata, E. albifrons, H. griseus and C. ferox, the Makira Forest is a culturally and ecologically unique geographical location and these results should not be extrapolated to other areas in Madagascar.

Hunting may be sustainable when there is a population density of 1.0 person $\mathrm{km}^{-2}$ living in a forest, if wild meat is the primary source of protein (Robinson \& Bennett, 2000). Surrounding the Makira Forest there is a population density 
of $>37$ people $\mathrm{km}^{-2}$, which suggests that if wild meat is their primary source of protein then hunting is probably unsustainable for many species. In terms of species biomass, the Makira Forest appears to be a small-scale hunting system because no large ungulates or rodents are harvested, as they are in many parts of mainland Africa. However, in terms of threats to species survivorship, the hunting regime in the Makira Forest presents an imminent warning to conservationists. Moreover, because the hunting of protected species is so widespread across households, any conservation intervention will require the addressing of the needs and concerns of the community and cannot be targeted at particular individuals.

Madagascar is an island nation facing economic difficulties and deforestation. With these additional factors compounding the threat of hunting, the endemic and threatened mammals of Madagascar, despite many having legal protection, are still in need of focused conservation efforts. Legal protection without the endorsement of local people cannot necessarily create successful conservation solutions. Madagascar, like many other developing and developed countries, has often neglected to include resource extraction and ecosystem services in the discourse of protected area design. This is of both national and international concern because Madagascar could provide an excellent case for the inclusion of local resource use in conservation planning. With the implementation of the Durban Vision further research is required to investigate the impacts of the expansion of protected areas on local people's forest resource use and hunting behaviour.

Since the collection of this data, research in the Makira Protected Area has continued and expanded, with the tracking of households seasonally and annually, to understand how increased management and protection may influence local decision-making regarding illegal hunting. Epidemiological studies investigating the relationship of human nutrition to seasonal bushmeat hunting are currently under way. Once data collection is complete reports will be passed to the appropriate agencies.

\section{Acknowledgements}

I would like to thank the Government of Madagascar, the Association National pour la Gestion des Aires Protégées, the Direction des Eaux et Forêts, and all of the welcoming residents of the Makira Forest for permission to conduct research. Funding and facilitation was provided by the Wildlife Conservation Society, the Harvard Committee for African Studies, and the Harvard Center for International Development. Special thanks are due to my research assistant Be Jean Rodolph Rasolofoniaina, and my advisors Richard Wrangham, Glenn Adelson, Claire Kremen and Justin Brashares. Additional thanks are due to Helen Crowley, Russ Mittermeier, Christopher Holmes, Pat Wright, Luke Dollar and David Wilkie.

\section{References}

BARnES, R.F.W. (2002) The bushmeat boom and bust in West and Central Africa. Oryx, 36, 236-242.

Bollen, A. \& Donati, G. (2006) Conservation status of the littoral forest of south-eastern Madagascar: a review. Oryx, 40, 1-10.

Brashares, J.S., Arcese, P., Sam, M.K., Coppolillo, P.B., Sinclair, A.R.E. \& Balmford, A. (2004) Bushmeat hunting, wildlife declines, and fish supply in West Africa. Science, 306, $1180-1183$.

CIA WORLD FACTBOOK (2008) Madagascar. Https://www.cia.gov/ library/publications/the-world-factbook/geos/ma.html [accessed 29 January 2009].

Cole, L.C. (1954) The population consequences of life history phenomena. Quarterly Review of Biology, 29, 103-137.

DEWAR, R.E. (1984) Extinctions in Madagascar: the loss of the subfossil fauna. In Quaternary Extinctions (eds P.S. Martin \& R.G. Klein), pp. 574-593. University of Arizona Press, Phoenix, USA.

Duffy, R. (2006) Non-governmental organizations and governance states: the impact of transnational environmental management networks in Madagascar. Environmental Politics, 15, 731-749.

FA, J.E., Peres, C.A. \& Meeuwig, J. (2002) Bushmeat exploitation in tropical forests: an intercontinental comparison. Conservation Biology, 16, 232-237.

Fitzgibion, C.D., Mogaka, H. \& Fanshawe, J.H. (1995) Subsistence hunting in Arabuko-Sokoke forest, Kenya, and its effects on mammal populations. Conservation Biology, 9, 1116-1126.

Garcia, G. \& Goodman, S.M. (2003) Hunting of protected animals in the Parc National d'Ankarafantsika, north-western Madagascar. Oryx, 37, 115-118.

Goodman, S.M. (2006) Hunting of Microchiroptera in southwestern Madagascar. Oryx, 40, 1-4.

Goodman, S.M. \& Benstead, J.P. (2005) Updated estimates of biotic diversity and endemism for Madagascar. Oryx, 39, $73-77$.

Goodman, S.M. \& Raselimanana, A. (2003) Hunting of wild animals by Sakalava of the Menabe region: a field report from Kirindy-Mite. Lemur News, 8, 4-6.

Hakeem, A., Sandoval, R.G., Jones, M. \& Allman, J. (1996) Brain and life span in primates. In Handbook of the Psychology of Aging, 4th edition (eds J.E. Birren \& K.W. Schaie), pp. 78-104. Academic Press, San Diego, USA.

Harvey, P.H., Martin, R.D. \& Clutton-Brock, T.H. (1987) Life histories in comparative perspective. In Primate Societies (eds B.R. Smuts, D.L. Cheney, R.M. Seyfarth, R.W. Wragham \& T.T. Struhsaker), pp. 181-196. University of Chicago Press, Chicago, USA.

Haw Kins, C.E. (2003) Cryptoprocta ferox, fossa. In The Natural History of Madagascar (eds S.M. Goodman \& J.P. Benstead), pp. 1360-1363. University of Chicago Press, Chicago, USA.

HAWKINS, C.E. \& RACEY, P.A. (2005) Low population density of a tropical forest carnivore, Cryptoprocta ferox: implications for protected area management. Oryx, 39, 35-43.

IUCN (2008) 2008 IUCN Red List of Threatened Species. IUCN, Gland, Switzerland. Http://www.iucnredlist.org [accessed 15 July 2008].

Milner-Gulland, E.J. \& Bennett, E.L. (2003) Wild meat: the bigger picture. Trends in Ecology and Evolution, 18, 351-357.

Powzyk, J. \& Thalmann, U. (2003) Indri indri, indri. In The Natural History of Madagascar (eds S.M. Goodman \& J.P. Benstead), pp. 1342-1344. University of Chicago Press, Chicago, USA.

Randriamanalina, M.H., Rafararano, L., Babary, L. \& Laha, R. (2000) Rapport des enquêtes sur les chasses dans les Fotontany d'Ivondro, d'Erara et d'Etsilesy. Lemur News, 5, 11-14. 
Rasolofoson, D., Rakotondratsimba, G., Rakotonirainy, O., Rasolofoharivelo, T., Rakotozafy, L., Ratsimbazafy, J. et al. (2007) Le bloc forestier de Makira charnière de lémuriens. Lemur News, 12, 49-53.

Robinson, J.G. \& Bennett, E.L. (2000) Carrying capacity limits to sustainable hunting in tropical forests. In Hunting for Sustainability in Tropical Forests (eds J.G. Robinson \& E.L. Bennett), pp. 13-30. Columbia University Press, New York, USA.

Robinson, J.G. \& Bennett, E.L. (2004) Having your wildlife and eating it too: an analysis of hunting sustainability across tropical ecosystems. Animal Conservation, 7, 397-408.

Robinson, J.G. \& Redford, K.H. (1991) Sustainable harvest of Neotropical forest animals. In Neotropical Wildlife Use and
Conservation (eds J.G. Robinson \& K.H. Redford), pp. 415-429. University of Chicago Press, Chicago, USA.

\section{Biographical sketch}

Christopher Golden has spent several years in Madagascar and is fluent in Malagasy. In collaboration with the Wildlife Conservation Society, and through funding from Conservation International, he has initiated a bushmeat monitoring programme in the Makira Protected Area and Masoala National Park. His current areas of interest and research include the interface between nutrition and forest resource extraction, the assessment of sustainability in bushmeat exploitation, and the investigation of how local decision-making with regard to exploitative behaviour is affected by varying management and protection schemes. 